\title{
Environmental Conflict and United Nations Environment Programme (UNEP) Report: An Appraisal of the Clean-Up in Ogoni
}

\author{
Dr Porbari Monbari Badom ${ }^{1}$, Barieeba Gbogbara² \\ ${ }^{1}$ Email: philanluv@yahoo.com \\ ${ }^{1}$ Department of Sociology, Faculty of social sciences, \\ University of Port Harcourt, Rivers State, 500272, Nigeria. \\ ${ }^{2}$ Department of Sociology, Faculty of Social Sciences, \\ Ignatius Ajuru University of Education, Rumuolumeni, Port Harcourt, 500272, Nigeria.
}

\begin{abstract}
The people of Ogoni over the years have been at logger heads with the federal government of Nigeria and the Multinational Company, Shell over the long period of oil exploration and exploitation on their land without any noticeable development, instead the environment was polluted. This is revealed by UNEP and shows that the Ogoni people have suffered grave consequences owing to the oil pollution of their land. Upon the recommendations of UNEP, the Federal Government agreed to clean up Ogoniland so as to save the people's lives and their environment. Against, this background, this study examined the environmental conflict and UNEP report in Ogoniland, with a view to appraising the clean-up projects in Ogoni. The study was exploratory and descriptive in design, thus the study relied on content analysis. Max Weber's strand of conflict theory was adopted as theoretical guide. Four objectives and corresponding four research questions were posed. In proffering answers to the questions, it was revealed that the several years of oil pollution in Ogoni breeds environmental pollution and grave dangers for the Ogonis. Thus, the cleanup was meant to clean the environment and restore the economy, wealth and health of the Ogonis. However, the present state of the clean-up is slow, delayed and reveals a lackadaisical attitude of the government which implies that the Ogonis are continuously affected by the hazard on daily basis.
\end{abstract}

Keywords: Clean-up; UNEP Report; Interest; Environmental Pollution; Ogoni(s); Environmental Conflict; HYPREP.

\section{Introduction}

The issue of environmental conflict existed between the Ogonis on the one hand and Shell Petroleum Development Company (Nigeria) Limited (SPDC) and the government of the Federal Republic of Nigeria, on the other hand, which emanated from the Ogoni people's realization that their environment had been plundered by oil exploration and they are denied compensation and relative development. Thus, the oil wealth was used to develop other parts of the country where government leaders have inherent interest. This had resulted to the utter neglect of the Ogonis. It is pertinent to note that the reality of this situation is 
an offshoot of the leadership capitalist orientation. Such capitalist outplay is the real motive behind the neglect of the Ogonis, their plight, nay exploitation.

The Ogonis have been conscious of their plight and expressed chagrin and conflict with Shell Petroleum Development Company since oil was discovered in 1958, during the period of British colonial rule, and the Ogonis as a Minority ethnic group amongst other groups were conscious and disagreed with their exploitation, international crisis group (as cited in Jaja \& Obuah, 2019). The key players in the oil exploration of Ogoni, namely Shell Petroleum Development Company (SPDC) and Federal Government of Nigeria continued with the oil exploration without any conscious effort to develop the oil communities. This became more conflicting when the Ogonis and their environment suffered the ills of oil pollution and exploitation against their interest. There were constant oil spills and uncontrolled flares without a quick response.

In order to combat and stop the environmental impacts of oil production, the Movement for the Survival of the Ogoni People (MOSOP) was founded and headed by Ken Saro-Wiwa (UNEP, 2011). Ken Saro-Wiwa criticized the oil companies and the governments' oil policy and brought international attention to the Ogoni cause (Ibid). Consequently MOSOP presented the Ogoni bill of right, which among others clamoured for their political autonomy and compensation for the damages inflicted on the Ogoni environment. "The unemployment rate in this area is extra - high, due to lack of economic opportunities, with youths resorting to farming and fishing but such activities are usually futile because of massive water pollution" (Jaja \& Obuah, 2019). Saro-Wiwa together with 300,000 Ogoni in 1993, embarked on a march calling for fare and equitable share of oil produce. This was not amicably heeded by the oil companies and shell and the federal government of Nigeria. This is deludingly exploitation from their quest to profit from the proceeds of oil produced on Ogoni land, yet they alienated the Ogoni people.

Ogoni in the heat of this conflict situation stopped oil production on their land. This resulted to a hullabaloo and the military were sent in by the government to quell the situation and to enable oil production. The Ogoni suffered hard casualties and they successfully decommissioned some oil facilities. This was not pleasant to the Federal Government who lost some millions of dollar and as such affected the economic deals of the government. Darah (2004) emphasized that:

The Ogoni struggle... struck at the heart of Nigeria's existence as an economic and political entity. Just as Jaja (of Opobo) and Nana (Olomu) in the $19^{\text {th }}$ century were seen by the British as "dangerous examples", so was Ken Saro-Wiwa and the MOSOP classified as "subversive models" for the rest of the Niger Delta. The oil also United the power systems that benefit the most from the exploitation and subjugation of the Niger Delta, namely, the Federal government of Nigeria and shell ... representing the multi-nationals and the global wing of the imperial tenor against the region. This explains the ruthless application of maximum 
force to squelch the struggle. The Scorch-earth repression and deaths that followed... are reminiscent of the dreaded Nazi reprisals in Germany and the Pogroms perpetrated under apartheid in South Africa.

Sequel to the declaration of Shell as persona non grata on Ogoni land and the swift resilience of the Ogonis, the federal government was more worried over the cut in revenue it resulted to. Ken Saro-Wiwa and the activities of MOSOP were keenly monitored by the federal government. Saro-Wiwa and eight of his kinsmen were arrested, tried and subsequently hanged on November 10,1995. This happened as a result of the "single event which changed the face of the entire struggle. This was the brutal murder of four of the most prominent sons of Ogoni land in circumstances that the state believed implicated a militant wing of the youths who were said to be under the control of Saro Wiwa" (Kukah, 2011). As a result of the deaths and that of Saro Wiwa the conflict was intensified. "While the Ogonis licked their wounds, they also felt satisfied by the fact that they had managed to expel Shell from their land" (Kukah, 2011, p.90).

As most of Shell's facilities in Ogoniland were commissioned, there were some pipelines that carried Oil produce in other parts of Nigeria through Ogoniland and have not been properly managed. This led to the oil infrastructural deterioration which caused further oil pollution and increased the environmental damage, (UNEP, 2011). There were series of efforts made by the federal government, international and national NGOs, faith based organisations, etc. to restore peace in Ogoniland (Kukah, 2011). Finally, the Ogonis were elated at the setting up of the human rights violation commission, or the Oputa (Commission by former President Olusegun Obasanjo) which in 2001 resolved the fissure in MOSOP, nay the families of Ogoni 4 and Ogoni 9 were reconciled, noting that "it is plausible under the circumstances to argue that actually, it was the Nigerian State that set the scene for the dance of death that took place in Ogoniland. The Ogonis were actors on a script written by the colonial state but which had been dusted up by the military state", (Kukah, 2011, p.156). Also, the positions of Shell and the government on the exploitation and damage of the Ogoni environment were noted. The reconciliation process was amongst other terms as part of its process gave the mandate to appoint an impartial international agency that would conduct an environmental assessment and supervise the clean-up process of the areas impacted by oil operations in Ogoniland (FRN, 2016; UNEP, 2011).

This clean-up process was billed to continue for between 25 through 30 years for the Ogonis to have a fresh and clean environment again, Soni (2016) cited in (Nwone, 2017). Thus, by July 2006, the United Nations Environment Programme (UNEP) was chosen by the federal government to carry out the scientific assessment of the environmental and public health impacts of oil contamination in Ogoniland with the mandate to recommend on the clean-up process. At this point the Ogonis were excited and they welcomed the UNEP with hopes of termination of the impacts dawned on them as a result of the long years of oil pollution. Ogoniland covering around $1,000 \mathrm{~km}^{2}$ had witnessed oil operations since the late 1950s. UNEP in the scientific investigation and observation did observe that "oil contamination in Ogoniland is 
widespread and severely impacting many components of the environment" (UNEP, 2011, p.9). UNEP found shell culpably responsible for the high level and widespread oil pollution that demands a process of clean-up of the environment that will last up to 25 through 30 years. Son, (2016) in (Nworu, 2017; Nyiayaana, 2018).

UNEP carried out the environmental assessment of Ogoniland and submitted its report to the federal government on $4^{\text {th }}$ August, 2011. It among others recommended the establishment of the Hydrocarbon pollution Restoration Project (HYPREP) to initiate and develop work programmes aimed at restoring Ogoniland and other impacted host communities (FRN, 2016; UNEP, 2011). To reposition Ogoniland entails a lot as given out by UNEP. Having observed in their investigation that the Nigerian State had failed to improve the living conditions of Ogoni people, the recommendations given by UNEP gave the world and the Ogoni people a high level of hopes of the government's bid to clean-up Ogoniland. However, "the Ogoni people view the clean-up project as transcending the Nigerian State's narrow technical efforts to remediate and restore the polluted and damaged environment", (Nyiayaana, 2018). Similarly, Jaja and Obuah (2019) observed that the pace with which the government is going about the implementation has given some skepticism about the sincerity of government to implement the UNEP report on Ogoni. This therefore evokes the curiosity of these researchers to explore the nature of the cleanup exercise in Ogoniland. This is more so for the fact that intellectual response on the issue of Ogoni cleanup is yet to fill this gap.

\subsection{Statement of the Problem}

Ogoni had had a long history of oil exploration and exploitation that dates back to 1958, when Nigeria was still colonized by Britain. The Ogonis did not have any say in the matters that concerned them, international crisis group, (2008) cited in (Jaja Obuah, 2019). This conflict seen as a result of colonialism and capitalism, Osha (2006) cited in Jaja \& Obuah. It was this seed of capitalist exploitation that was sown in the elites who took over government from the British. The civilian and military government that had ruled Nigeria from 1960 when "Nigeria gained political independence had politicians and rulers who emerged as the dominant class that accumulated wealth either directly or in any form of representation, and are in position to determine what others will get (Anikpo, 1996). On the other hand, the Ogonis became the exploited people who had no say in matters concerning them. Thus the capitalist government conceived of means to take what belong to the Ogonis. As oil was discovered in Ogoni in 1957 by Shell Petroleum Development Company (SPDC), a plethora of oil companies moved into Ogoniland. Oil exploration and mining took an incremental level and the government was aware of the wealth oil mining generates, it asked the Ogoni people to abdicate their land without any compensation and consultation. To actualize it, the government gave the action legal crutch as it promulgated a decree in 1978. Such decree gave landownership to the government against the collective interest of the Ogonis, (Jaja \& Obuah, 2019). 
Since then the government had greatly benefited from the oil proceeds mined by Shell which acts as its agent in exploitation. The Ogonis presented a bill of right and in it demanded a fair share of proceeds generated from their land, which the government and Shell refused. After series of protests and consequent deaths of Ogoni leaders, a reconciliatory commission recommended an impartial scientific assessment of Ogoniland. Reports emanating from UNEP revealed that Ogoniland was contaminated, and recommended a clean-up of their land. Owing to the public outcry to the plight of the Ogonis, the government decided to constitute HYPREP to commence the clean-up of Ogoniland. It has been observed that the government has not shown more commitment as spelt out in the UNEP report to the clean-up. This had thus raised doubts in the minds of people whether the clean-up will achieve the objective it was designed for.

It is therefore observed that the federal government's effort is geared towards deception of the Ogonis. There is therefore the need to examine the clean-up process and appraise its conformity with recommended process. This is pertinent owing to the fact that Ogoni people are still experiencing their dangerous environment; they continue to drink the benzene contaminated water among other grave dangers. Intellectual response on this issue has been scanty. For instance, Jaja \& Obuah (2019) conducted a qualitative study on the politics of the Ogoni clean-up: challenges and prospects. It failed to do a thorough appraisal of the clean-up process. Also, Sobomate (2014) did a study on environmental justice in Nigeria with a penchant on the reflections on the shell - Ogoni uprising, twenty years afterwards. This study focused on other intricacies of the Ogoni struggle but did not do a thorough appraisal of the clean-up process. In another study, Nworu (2017) studied "Ogoniland clean-up, remediation and satisfactory environment favourable to its development: obligations of the Nigeria State. It was more concerned with the obligations of the Nigeria State but rather failed to appraise the clean-up process. In a different study, Bodo (2018) did a qualitative study "community understanding of the environmental and socio-economic consequences of petroleum exploitation in Ogoni, Rivers State Nigeria”. This study concentrated on the consequences of petroleum exploitation in Ogoni. Finally, Poroma \& Igwe (2020) did a qualitative study on “Ogoni UNEP report: a panacea for conflict resolution in the Niger Delta. It reveals government's nonchalant attitude towards the clean-up and the consequences of non-implementation of UNEP report. Thus, the gap left will be filled in this study.

\subsection{Statement of Objectives}

The overall objective of this study was to render a critical appraisal of the clean-up project in Ogoni. The specific objectives were:

(i) To explore the conditions that necessitated the clean-up project.

(ii) To examine the expected role of the clean-up project.

(iii) To examine the present state of the clean-up project.

(iv) To examine the implication of the present state of the clean-up. 


\subsection{Research Questions}

The study sought to answer the following questions:

(i) What condition necessitated the initiation of the clean-up project?

(ii) What role is the clean-up project expected to play?

(iii) What is the present state of the clean-up project?

(iv) What implication does the present state of the clean-up portray?

\subsection{Theoretical Framework}

This study was anchored on conflict theory strand of Max Weber. This perspective focuses on the rational behind rational actions taken by individuals. "The first of this is means-ends rationality; or action that is determined by expectations as to the behaviour of objects in the environment and of other human beings; these expectations are used as "conditions" or "means" for the attainment of the actor's own rationally pursued and calculated ends". Weber cited in (Ritzer, 2008, p. 127). Weber also consigns society to involve stratification which is multidimensionally caused. People of a particular class strive for a common goal. A class according to Weber according to Ritzer (2008) means a group of people whose shared situation is a possible, and sometimes frequent, basis for action by the group. According to Weber a "Class situation" exists when three conditions are met:

(1) A number of people have in common a specific causal component of their life chances, in so far as;

(2) This component is represented exclusively by economic interests in the possession of goods and opportunities for income; and

(3) Is represented under the conditions of the commodity or labour markets.

From this prepositions, it is clear that the Ogonis and the government are at polar ends in terms of their interests. The government through its agencies and collaborators is solely interested in the accumulation of wealth derived from the land of the Ogonis without a fair share to the people of Ogoni who are all conscious of their deprivations under the oil company. Shell as an agent of the federal state is a global capitalist firm that pervades the Nigeria fields and their oil exploration and exploitation compromise enormous standard, Obi cited in (Myapyen \& Bozkurt, 2020, p.5). The acceptance of UNEP recommendations to clean-up Ogoniland by the government of Nigeria is solely because of the unwavering intent to generate wealth from Ogoniland. They so pretend that they are serious with the clean-up of Ogoniland, yet the pace of the clean-up portrays no true will to develop Ogoni. The clean-up as perceived serves as "conditions" or "means' for the government and Shell to achieve their pursued and calculated end. Thus, the Ogonis do not want, hence, the conflict. This environmental conflict between the Ogonis and the federal government of Nigeria together with the oil company is associated with capitalism (Osha, 2005). Nigeria is a dependent capitalist nation (Anele, 2003). The Nigerian State has assumed different forms such as colonial, parliamentary, stato-cratic, presidential, stato-cratic and back to presidentialism. In spite of which ever form, it is still the bourgeois state (Ibid). This means that whichever form of 
government Nigeria assumed, there is still a common interest; that of the burgeoning national leaders to exploit the Ogonis without a true interest in developing their environment. Instead, they try to legitimate a law as a means of exploiting the Ogonis. Weber contends that authority, legitimized on rational grounds "rests on a belief in the loyalty of enacted rules and the right of those elevated to authority under such rules to issue commands" Weber cited in (Ritzer, 2008). This is also supported by Dahrendorf (1959) stressing the latency of conflict of interests within any society and the dominant position strives to maintain the status quo while the subordinates the Ogonis seek change. It is here reiterated that the federal government of Nigeria seeks to maintain the status quo through rationalizing rules. This explains the reason for the promulgation of Nigeria's 1978 land use decree, an obnoxious rational legalization of arrogating the Ogonis' wealth to them. Furthermore, the government's resolve to embark on the Ogoni clean-up is delayed and may not be done as recommended owing to their capitalist orientation.

\subsection{Methodology}

The study was exploratory and adopted a cross-sectional research design. Data were generated through content analysis, giving preference to narrative technique of reporting. In this way, all related literature were analysed descriptively.

\subsection{Discussion}

This section discusses the findings of the study that were hinged on the research objectives outlined in this study. The findings were presented in the manner of the corresponding research questions were presented and were done logically

\subsubsection{Conditions that Necessitated the Initiation of the Clean-up Project}

The federal government of Nigeria was compelled by the conflicting situation and subsequent protests by the Ogonis to invite an independent body, UNEP to study the frequent oil pollution of the Ogoni environment and give recommendations. UNEP did a thorough scientific investigation of Ogoni land and presented a pathetic case which the Ogonis have.

It is clear from UNEP's field observations and scientific investigations that oil contamination in Ogoniland is widespread and severely impacting many components of the environment. The Ogoni people live with this pollution every minute of everyday, 365 days a year. Since average life expectancy in Nigeria is less than 50 years, it is a fair assumption that most members of the .... Ogoniland community have lived with chronic oil pollution throughout their lives, children born in Ogoniland soon sense oil pollution as the odour of hydrocarbons pervades the air day in, day out. Oil continues to spill from periodic 
pipeline fractures and the illegal practice of artisanal refining, contaminating creeks and soil, staining and killing vegetation and seeping meters deep into ground, polluting water tables. Smoke from artisanal refining is a daily presence and fire close to inhabited areas is a constant threat from pools of oil which gather after a spill due to corrosion or bunkering... (UNEP, 2011, p. 204).

The above extract revealed the dangerous situations which the Ogonis are placed by virtue of their position as host to oil exploration. This includes the four kingdoms of Ogoni. These kingdoms are; Gokana, Tai, Eleme and Khana. UNEP revealed that Ogoniland environment is widely and surely impacted by the oil contaminations. This continually happened as a result of regular oil spills even though the oil exploration is no longer active in the Place. This had thus left an unending scar on the Ogoni environment placing the natives at the threshold of death and possible extinction.

In specific terms, Ogoni communities as a result of the oil exploration have contaminated soil and ground water. Oil pollution in many inter-tidal creeks has damaged vegetation. This includes mangroves, and crops. Also, (UNEP, 2011) reports that the floating layers of oil which contains hydrocarbons has destroyed the fisheries sector, by destroying fish habitat in the mangroves making it unsuitable for fish to live. This had thus destroyed fish farms close to the creeks owned by entrepreneurs.

Similarly, UNEP (2011:10) reports that "the Ogoni community exposed to petroleum hydrocarbons in outdoor air and drinking water", sometimes at elevated concentrations. They are also exposed through derived contacts from contaminated soil, sediments and surface water." This raises a health issue as it stressed that "since average life expectancy in Nigeria is less them 50 years, it is a fair assumption that most members of the current Ogoniland community have lived with chronic oil pollution throughout their lives.

These grave conditions in which the Ogonis live are corroborated in another study. CEHRD (2019) revealed some intricately related conditions and impacts of the oil contamination on the Ogonis. The following facts are based on this baseline study. It found that sequel to oil pollution of Ogoniland its "biodiversity and livelihood dependent ecosystems have been seriously affected. In this case, ground water such as bore wells (i.e. boreholes) and dug-out wells (i.e. wells dug by hand) are contaminated and thus drinking water is no longer safe for drinking. Similarly, the people's once reliable agricultural produce are gradually being destroyed and thus "the rich mangrove communities are now shadows of themselves". Also, most wildlife species earlier seen in their creeks and rivers before the oil pollution are rarely seen or totally gone into extinction. 
This had therefore resulted to the loss of livelihood as most natives depend on these sources as means of wherewithal. CEHRD (2018) stressed that "environmental pollution impacts men and women disproportionately, given the different roles and responsibilities in the household and community levels."

This way, it is found by CEHRD $(2018 ; 2019)$ that women are vulnerable to the oil pollution as their main source of livelihood, farming has been destroyed. It is pertinent to point out that in most families women are caregivers and as such have their families deprived of their care and support in financial terms. It had thus resulted to financial hardship in most families. The hardship experienced by families in the communities has increased the occurrence of gender-based violence, which is reported to be widespread. Other vulnerable groups according to CEHRD are the children, adolescents and youth. Hence, crime rate has increased in Ogoni as those whose means of livelihood were terminated by the oil pollution resort to other meagre-income-jobs and criminal acts. Most young men resort to motorcycle transport business. Cultism, kidnapping and oil theft, most women on the other hand are prone to embrace prostitution which can increase the spread of sexually transmitted diseases including HIV/AIDS.

Furthermore, the Ogonis have suspended or lost most of their cultural practices sequel to the oil pollution of Ogoniland. CEHRD (2019, p. 125) found that the communities visited all have a rich cultural life that is deeply connected with the nature around them, and especially with the rivers and the crops. A report from CEHRD explores in detail the cultural rituals that some communities have in the Niger Delta. Some of the communities' rituals were affected by the contamination in the environment surrounding the communities, preventing them from maintaining the cultural richness of the group's traditions. The oil activity in the region having started 50 or 60 years ago, a few generations have therefore, never assisted or participated in the traditions that were an integral part of their community's life before oil contamination. In FGDS conducted by CEHRD, community members showed a fear that these cultural traditions would be lost to those generations and future ones. Specifically, there are many cultural practices related to the river. For instance, 'the kpoagbaa' ritual is a practice where women bath in the community creeks midnight of every December $31^{\text {st }}$. This is a symbolic way of purifying oneself from sickness, curses and bad omen of the year that is to end.

Culture is a source of people's social identity (Haralambos \& Holborn, 2008). Nigeria is a country where every tribe is culturally distinct and the 1999 constitution of the federal republic of Nigeria gives every tribe the power to enjoy social and cultural rights. So the Ogonis have a right to practice certain culture. Besides, CEHRD (2019) also found that Ogonis had health challenges because of the impacts of hydrocarbons released from oil pollution. These diseases include persistent cough, eye diseases, male and female infertility, sexually transmitted infections, skin diseases, learning problems etc.

These deplorable conditions discussed above amongst others are prevalent in Ogoni since the advent of oil exploration and relative pollution in Ogoni. UNEP having studied and revealed the condition, there was 
necessity to clean up Ogoniland, in a bid to restore the pride and wealth of Ogoni. President Buhari, ably represented by Vice President Yemi Osinbajo averred that:

The beginning of this clean-up exercise is the evidence to restore economic, wealth, health of the people, let this day mark the beginning of the restoration, not just of the Ogoniland, but of peace and prosperity to Ogoni people and that of the Niger Delta (Cornelius, 2006)

\subsubsection{The Anticipated Role of the Clean-Up Project}

The many years of oil exploration had resulted to severe environmental maladies which had thus relegated the health, economic and social conditions of the people of Ogoni. As a result, the people of Ogoni are in such grave danger arisen from oil exploration. The clean-up project as recommended by UNEP was greeted with admiration with the hope that it will address the plights which the oil exploration had caused. The vice President, Osinbajo stressed in (Cornelius, 2016) that "the beginning of this clean-up exercise is key evidence to restore economic, wealth, health of the people. Let this day mark the beginning of the restoration, not just of the Ogoniland, but of peace and prosperity to Ogoni people".

The clean-up project is expected to restore the environmental conditions that are inimical to healthy, environmental, safe social and vibrant economic wellbeing of the Ogonis. This will therefore, address the issue of contaminated land, groundwater, surface water, sediment, vegetation, air pollution, public health, industry practices and institutional issues.

UNEP (2011) emphasized that the restoration of Ogoniland is possible but may last up to 25 or 30 years, considering the longer years of oil exploration and pollution and resultant longer years impact. It stressed that the UNEP report "contains numerous recommendations that, once implemented, will have an immediate and positive impact on Ogoniland. Further recommendations have longer timelines that will bring lasting improvements for Ogoniland". UNEP (2011, p.15) stressed that "the overall cost of the cleanup should not be an obstacle to its implementation. Therefore, an environmental restoration fund for Ogoniland should be set up with an initial capital injection of USD 1 billion contributed by the oil industry and the government.

Furthermore, as the UNEP environmental assessment revealed, there are three groups in the Ogoniland were health and safety are seriously at risk owing to the environmental contaminations. There are; those exposed to hydrocarbon pollution in their drinking water, including one community where benzene concentration are extremely elevated", those living on oil pipeline rights of way, and; those involved in bunkering and artisanal refining". Their situation demands the provision of safe drinking water and the immediate stoppage of their drinking from the contaminated wells. Therefore, the clean-up project will enhance the provision of safe drinking water and stop the drinking from contaminated water. UNEP (2011, p. 207) states that "pollution of soil by petroleum hydrocarbons is widespread in Ogoniland - in land areas, 
in sediments and in swampy land". This, thus on UNEP recommendations demands the clean-up of contaminated soil and sediments. The clean-up product is expected that it will give attention to the treatment of contaminated sediments, restoration of contaminated soil in swampy areas, rehabilitation of mangroves and decontamination of ground water.

This will enable the soil to be fertile again. This will thus enhance the economic well being of the Ogonis. This is because the Ogonis are predominantly farmers and traditional fishers (Yakubu, 2017). The Ogonis as a local community have been faced with displacement, dispossession and exposure to risk (Howitt, 2001). When UNEP in its recommendations on the transition phase recommended the establishment of the Ogoniland Environmental restoration Authority (OERA), UNEP stated that it will carry forward the work to clean up and restore Ogoni environment. UNEP pointed out that the key objectives of the transition phase of the clean-up among others will be "preparing a socio-economic study for the development of a livelihoods strategy for Ogoniland; providing capacity building such as training, to support the working groups etc. in all, Ogoni environment is expected to take a new look that will enhance good health, people's economic well-being, and development.

\subsubsection{The Present State of the Clean-up Project}

The federal government of Nigeria, following the United Nations Environment Programme (UNEP) report on the environmental pollution and degradation of the richly endowed ground of the Ogoni people owing to longer years of oil production activities decided to establish an Ogoniland Environmental Restoration Authority, to oversee the implementation of the recommendations arisen from the UNEP's empirical study of Ogoniland, with a fixed initial life span of 10 years.

In a bid to conform to the recommendations of UNEP, the federal government of Nigeria established the Hydrocarbon Pollution Remediation Project (HYPREP) with the intent to achieve the following objectives in Ogoniland and other impacted communities:

- Determine the scope, modalities and means of remediation of soil and ground, water contamination in impacted communities as may be approved by HYPREP governing council and remedy them;

- Enhance local capacity for better environmental management and promote awareness of sound environmental management as well as ensure livelihoods and sustainable development;

- $\quad$ Ensure security and promote peace building efforts in impacted communities; and

- Strengthen governance, transparency and accountability in the region.

FRN (2016) stipulates that HYPREP shall perform the following functions:

- Investigate, map and evaluate hydrocarbon polluted communities and sites in Nigeria referred to it by National Oil Spill Detection Response Agency (NOSDRA) or the federal Ministry of Environment in Collaboration with the Department of Petroleum Resources (DPR) and make recommendations to the Federal Government; 
- Implement the recommendations of the United Nations Environment Programme (UNEP) report on Environmental Restoration of Ogoniland (UNEP Report) as directed by the HYPREP Governing Council;

- Initiate, and develop work programmes aimed at restoring all hydrocarbon impacted communities and sites referred to HYPREP;

- Undertake a comprehensive assessment and mapping of all environmental issues associated with hydrocarbon pollution in collaboration with (NOSDRA);

- Provide guidance data to undertake remediation of contaminated soil and ground water in Ogoniland and her impacted communities as maybe referred to it;

- Technically evaluate alternative technologies to be employed to undertake remediation of contaminated soil and ground water;

- Make recommendations for responding to future environmental contamination from hydrocarbons; and

- Ensure full environmental recovery and restoration of Ogoni ecosystem and services for Ogoni people and other impacted communities.

With the establishment of HYPREP and with the above mandate, people of Ogoni and the world were optimistic that the Ogonis would soon heave a sigh of relief from the long years of environmental degradation. However, the achievement and slow pace with which the government of the federal republic of Nigeria is going about the implementation of the UNEP report has evoked a somewhat feeling of despair in Ogonis and those who are following up the implementation of the Ogoni clean-up. The "first phase" of the clean-up that was flagged up on June 2016 by President Mohammadu Buhari has also been delayed in the implementation process. This is in consideration of the fact that the first phase was planned to last for a specific period, and with how many years gone with the slow pace of work is questionable.

HYPREP (2021) stressed that the Federal Government has flagged off the phase 1 of the construction of six water projects in continuation of her commitment to the full implementation of the UNEP report in Ogoniland. It reported that Dr. Mohammed Mahmood Abubakar, the Minister for Environment stated that Federal Government has approved funds for the provision of portable water to some impacted communities in Ogoniland. The Minister was reported to have said that the phase one of the water project will cover the following communities: Bori/Kpean; Barako/B-Dere/K-Dere; Terabor; Korokoro/Nonwa; Alesa and Ebubu/Nsisioken/ Ogale and that additional eight water projects will soon be rolled out. In addition, Dr. Abubaker was reportedly mentioned that remediation work was completed in 16 out of the 21 sites in the phase 1, batch 1 contacts, while 6 have been certified by NOSDRA and flood out.

However, despite the claims of the government, what are seen in some of the communities mentioned above are mere empty borehole tanks. No water has yet been provided. As such the Ogoni people are presently viewing the empty tanks in those communities, yet consuming contaminated water. It appears that propaganda had been one of the tools, which the government had utilized to sustain the patience of the 
Ogonis. It was still this propaganda that was used by former regimes before the present government of President Muhammadu Buhari. Agbakwuru (2021) reported the Minister of Environment, Muhammad Mahmoud to have said that

This is a project that previous governments have tried to do, but it just turned out to just talk. But President Buhari in 2015 when he promised, this thing started in 2016 and currently, there will be six water projects that will be provided in this for local governments (Sic) of Ogoniland and this has just been approved and work will start immediately.

Inspite of this promise, the Buhari led-government of Nigeria had also been accused of using propaganda, even if the Ogoni people are still drinking from contaminated water. Godwin (2020) argued that "oil watch Nigeria has lamented those four years after the Vice-President, Yemi Obasanjo commenced the Ogoni clean-up, and the remediation process has no visible impacts so far". Similarly, Ebiri (2020) stated that the "Gbo Kabaari Ogoni," a socio-cultural group of elders in Ogoni had discredited the clean-up. They urged the federal government to urgently review the clean-up. This according to them is because since the UNEP revealed that Ogoni people are consuming contaminated water many years ago, "the government had not deemed it fit to provide the indigenes with a safer variant of the resource, thereby deliberately undermining the health and wellbeing of Ogoni people".

The elders accused the supervisory agency, the Hydrocarbon Pollution Remediation Project (HYPREP) of "engaging in propaganda to cover up its failures at the expense of the health and lives of the helpless people of Ogoni” (Ebiri, 2020). Again, the Youths and Environmental Advocacy Centre (YEAC) has equally observed the long delay by the government and HYPREP stressing that the first phase which was billed for five years, may last for more 22 years. If the pace of work is not accelerated it will not achieve the purpose for which it was initiated. "The group regretted that United Nations Environment Programme (UNEP) brokered remediation was virtually on a standstill" (Ebiri, 2020). They observed that between June 2, 2016 and June, 2020, HYPREP had spent four of the first five years of the project earmarked for 1 billion dollar. It was reported that the agency had received 360 million dollar from which it said it had expended 44 million dollar during the period (Ibid). Also, Uwaegbulam (2020) emphasized that national assembly members have frowned at the delay in the remediation on the polluted areas in Ogoniland. They equally queried the use of unreliable laboratories. With the same level of concern, Godwin (2014) stressed that friends of the Earth, Amnesty International, and Centre for Environment, Human Rights and Development (CEHRD) revealed that the Nigerian Government and Shell are unserious and slow to clean up the widespread pollution in Ogoniland, not withstanding UNEP recommendations.

Furthermore, the communities in Ogoni have reportedly viewed the government's slow handling of the clean-up as sheer political will not to clean-up Ogoni, but rather a decoy of the willingness to develop 
Ogoni, so as to be allowed to re-enter Ogoni and further its interest of oil exploration against the interest of the Ogonis. This is more as apparent as they are denied the presence of portable water in their communities. There is thus the widespread notion of the seeming display of the political will not to clean up Ogoniland at quick pace to save the people from living in contaminated environment. Ogoni people have not been paid the compensation. These are people whose means of livelihood have been destroyed. The UNEP report recommended payment of compensation to the people of the affected communities (Poroma \& Igwe, 2020). The clean-up has phases and programmes of implementation, from indications the activities projected for the first phase are still not done. The communities in Ogoni are still drinking from the benzene contaminated water and the time billed for the first phase will soon elapse. This is an indication of the government and Shell's lackadaisical approach to the clean-up projects. Thus, the Ogonis are still being affected by the contaminated environment where they live.

\subsubsection{Implications of the State of Clean-Up}

The present state of clean-up in Ogoni communities indicates the federal government and Shell's whimsically lackadaisical approach to the issue of cleaning up the contaminated environment. It is an indication of total exploitation of the Ogonis without recourse to UNEP recommendations, thereby depriving the Ogonis of the opportunity to live healthy and wealthy lives in their previously vibrant economic terrain. It thus indicates that the Ogonis will continually live in an underdeveloped, unhealthy, nay environmentally polluted environment with relative consequences. UNEP in its report stressed that oil contamination in Ogoniland is widespread and severely affecting many components of the environment. This revealed the intricacies of associated impacts on the Ogonis. It is an established fact that the soil and groundwater are polluted. This indicates that the soil is not fertile for farming. Farming is a major economic activity in Ogoni. As such many if not all indigenes resort to farming as a means of livelihood. It then means that Ogonis will continually have a distorted economic source. This could result in primary and other grave consequences respectively. An instance of this is when CEHRD $(2018$, p.18) stressed that "women in the region resort to involvement in illegitimate ventures in efforts to meet the needs of their families...some women engage in prostitution in order to earn income for family upkeep. The practice undermines women's self-esteem, and affects their psyche overtime". The increased pace of oil bunkering in Ogoni is also attributed to the loss of livelihood made possible by the contamination of the Ogoni environment. Ogoni people are thus perennially in poverty. It is therefore deduced that the present state of the clean-up is an indication that the government and Shell want the Ogonis to continually live in perpetual poverty and hardship.

Besides, the fact that the clean-up is in the present state, where even portable water have not been provided apart from the few empty tanks, implies that the people of Ogoni are ever consuming the contaminated water. UNEP (2011) recommended inter alia that "everyone who has consumed water from contaminated 
sources should be requested to undertake a comprehensive medical examination by physicians knowledgeable about the possible adverse health effects of the hydrocarbons detected."

This necessitated the emergency measures recommended by UNEP, among which it emphasized the provision of adequate sources of drinking water to these households whose drinking water supply is impacted. For the moment, no water is yet provided. As such, it implies that the Ogonis are continually drinking from the contaminated water. This will no doubt exacerbate the health hazard of relying on such contaminated water for the long period Ogonis had consumed such unhealthy water. A baseline study conducted by CEHRD (2019) found that surface and ground water quality is adversely affected by the oil pollution in Ogoniland. Consequently, it is no longer suitable for human consumption. It therefore implies that Ogonis are continually consuming the polluted water which had sorely affected and will continually affect their health. This is consequently affecting the life span of the Ogonis and sequel to this, most people may not attain the 50 years which according to UNEP (2011) less than 50 is the life expectancy in Nigeria.

Similarly, CEHRD (2019) found that there are several diseases suffered by Ogonis which are caused by oil pollution. These include; cardiovascular disease, skin diseases, persistent cough, eye diseases and infertility in both men and women etc. even if the clean-up was structured in phases to last for 30years, the pace of cleaning Ogoni does derails the hope and agreement to ensure that the environmental quality in Ogoni does not place the natives' health at a disadvantage compared to the rest of the social groups in Nigeria (Miapyen \& Bozkurt, 2020). The fact is thus presented that the government which has the mandate to protect its citizens' lives is apprised of the consequences of the slow pace of the clean-up on the Ogonis. This is in conformity with the argument by Pellow (2007) that the host communities are exposed to environmental hazards occasioned by poor handling of the situation and sometimes victims of this condition are neglected. To corroborate this fact, Buhari inherited the government in May, 2015 and promised to revamp the Ogoni condition. Despite the slow pace, delay and possibly a gimmick to clean Ogoniland, the federal government seems to be complacent with the state of the clean-up. The government seems to not understand the health condition of the Ogonis and, have overlooked these deplorable conditions owing to its exploitative interest. This is evident in the insistence of the federal government on the resumption of oil production in Ogoni simultaneously with physical cleaning of Ogoni environment that is yet to start and which was vehemently rejected by the Ogonis and thus generating a new agitation in Ogoniland (Nyiayaana, 2018). Overall, the present state of the clean-up project implies government's unseriousness, and negligence to the Ogonis owing to its exploitative orientation.

\subsubsection{Summary of Findings}

1. Ogoni environment and land are impacted by larger years of oil exploration and pollution and thus had contaminated Ogoni soil and ground water - a source of human consumption, and also damaged the ecosystem. 
2. Owing to the destruction of Ogoniland's biodiversity and livelihood dependent ecosystems, the Ogoni people have lost their years-long means of livelihood with a predisposition towards increasing gender-based violence and crime. It had also resulted to the suspension and loss of some Ogoni cultural practices.

3. The clean-up project upon its initiation was expected to restore the environmental conditions that are inimical to a healthy environment, safe social and vibrant economic wellbeing of the Ogonis.

4. Presently, the government is slow and delaying the implementation of the clean-up especially the first phase of the clean-up. Portable water has not been provided as recommended and Ogonis are continually consuming contaminated water.

5. The slow pace of the clean-up project implies government and Shell's unseriousness, negligence, insincerity and insensitivity to the plight of the Ogonis. Thus, it also implies government and Shell's exploitative interest that relegates and consigns the Ogonis to continually live in despondency, perpetual poverty and hardship.

\subsection{Conclusion and Recommendations}

The land of Ogoni has been subjected to oil mining since 1958. This oil mining was facilitated by the following oil fields; Bomu, Bodo West, Tai, Korokoro, Yorla, Lubara creek and Afam by Shell Petroleum Development Company Nigeria Limited. The mining in Ogoni thus far have provided the Nigerian nation with a total revenue estimated at over 40 billion Naira or 30 billion dollar, Ogoni Bill of Rights (as cited in MOSOP, 2002). Despite the economic gain accruable from the oil mining to the federal government of Nigeria, the government had deliberately refused to develop Ogoni. This sparked conflict and on the recommendations of UNEP, the federal government agreed and attempted to clean up Ogoniland which had in course of oil mining been polluted. This had therefore left the Ogonis in an unhealthy condition as they continue to consume benzene contaminated water. In fact, the Ogoniland is as a result turned to an environment fraught with ecological disaster.

When the federal government agreed to clean up Ogoni land on the orders of UNEP, the people were filled with joy and high expectations of the government. Since the oil pollution affected all the communities in the constituent kingdoms that form Ogoni, it was expected that the clean-up will be implemented lusciously to save the Ogonis. However, the federal government's slow pace and delay in the clean-up project and the earlier attempt to resume oil exploration concurrently with the clean up portrays a clandestine interest and the lackadaisical attitude of the government.

It implies that the government is exploiting the Ogonis without the real intent of developing them. This means that the Ogonis will continue to suffer the ills and dangers of oil pollution. The Ogoni communities are thus prone to diseases, loss of livelihood and dearth of food. In fact, the Ogonis are deprived of healthy environment and relative benefits. The clean-up will only address the ecological disaster on the Ogonis if 
the federal government hearkens to the recommendations of UNEP timely. The delay and slow pace of the clean-up consigns the Ogonis to neglect and continual suffering. Based on the findings of the study, the following recommendations were made;

1. The federal government of Nigeria and Shell should be sincere in their commitment to clean up Ogoni environment and eschew such negligence towards Ogonis.

2. The Federal Government and Shell should be apprised of the adverse effects dawned on the Ogonis and their continuous plight owing to the delay in the provision of portable water to the Ogonis and act fast.

3. The Federal Government should without delay provide portable water to the communities in Ogoni and hasten the clean-up process.

4. The Federal Government should show a sincere commitment towards the development of Ogoni.

5. The Federal Government of Nigeria should keep to the conditions spelt out in the UNEP report within the stipulated time it was billed for, to save the ecosystem, wellbeing and social heritage of the Ogonis.

6. Sequel to oil bunkering and the people's predisposition to other crimes induced by loss of means of livelihood, the government of Nigeria should pay the compensation to the affected people of Ogoni.

\section{References}

Agbakwuru, J. (201). Federal government approves N6bn for portable water in Ogoni bud.

Anele, K. A. (2003). The changing forms of the state: A discourse on Marxism and the state. Social dynamics monograph No.1. Port Harcourt: Luckozim Nigeria Limited.

Anikpo, M. (1996). Hegemonic legacies: Issues in the sociology of Nigeria's underdevelopment. Inaugural lecture series, No.16: University of Port Harcourt. Port Harcourt: University of Port Harcourt press ltd.

Bodo, T. (2018). Community understanding of the environmental and socio-economic consequences of petroleum exploitation in Ogoni, Rivers State, Nigeria: International Journal of advanced research and publications. 2(11), 51-55.

Center for Environment, Human Rights and Development (CEHRD) (2019). Environment, health, human rights and gender baseline for Ogoniland cleanup. 
Cornelius, E. (2016). adopting non-violence method to achieve clean-up of Ogoniland. Retrived from https://guardian.ng/features/using-npn-violence-to-achieve-clean-up-of-ogoniland.

Darah, G. G. (2004). The Ijaw nation: Develop or perish. Lecture delivered at the $2^{\text {nd }}$ national convention of the Ijaw Youth Council, Yenagoa, Bayelsa State, Nigeria.

Ebiri, K. (2020, June 04). Ogoni cleanup's first phase may last for more 22 years, youths warn, deplore slow pace of project. The Guardian. Retrieved from https://m.guardian.ng

Ebiri, K. (2020, September 08). Elders seek urgent review of Ogoni clean-up. The Guardian. Retrieved from https://m.guardian.ng.

Federal Republic of Nigeria (2016). Official gazette. Lagos: The federal government printer.

Godwin, A. (2020, November 19). Ogoni clean-up has no visible impact, group insists.The Guardian. Retrieved from https://m.guardian.ng.

Godwin, O. (2014). No progress: An evaluation of the implementation of UNEP's environmental assessment of Ogoniland, three years on. Report from Amnesty International, friends of the Earth. Retrieved from https://reliefweb.int/report/nigeria/no-progress-valuationimplementation-unep-s-environmental-assessment-ogoniland-three.

Haralambos, M.; Holbern, M. \& Heald, R. (2008). Sociology: Themes and perspectives ( $7^{\text {th }}$ Ed.). London: Harper Collins Publishers Limited.

Howitt, R. (2001). Rethinking resource management: Justice, sustainability and indigenous people. London: Routlege.

Hydrocarbon pollution remediation project (HYPREP) federal Ministry of Environment (2021). Ogoni clean-up: FG flags off six water projects. Retrieve from httpsL//hyprep.gov.ng.

Jaja, J. M. \& Obuah, E. (2019). The politics of the Ogoni clean-up: challenges and prospects. African research review. 13(3), 101-113.

Kukah, M. H. (2011). Witness to justice: An insider's account of Nigeria's truth commission. Bookcraft. 
Miapyen, B. S. \& Bozkurt, U. (2020). Capital, the state and environmental pollution in Nigeria. SAGE open. 1-10.

Movement for the Survival of the Ogoni People (MOSOP) (2002). Ogoni development blueprint. Port Harcourt: Dorbarine Press.

Nworu, O. C. (2017). Ogoniland clean-up, remediation and satisfactory environment Favourable to its development: Obligations of the Nigeria State. World environment 7(2), $31-41$.

Nyiayaana, K. (2018). The state an the environmental clean-up in Ogoni: Building peace or the continuation of oil politics in the Niger Delta? Retrieved from https://kujengaamani.ssrc.org/2018/09/18/the-state-and-the-environment-clean-up-in-ogoni,

Osha, S. (2005). Birth of the Ogoni Movement. Journal of Asian and African Studies. 41 (1/2), 13 - 38.

Pillow, D. N. (2007). Resisting global toxics: Transnational movements for environmental justice. MIT Press.

Poroma, C. L. \& Igwe, R. O. (2020). Ogoni UNEP report: A panacea for conflict resolution in the Niger Delta. International journal of social sciences and humanities reviews. 10(1), $112-121$.

Ritzer, G. (2008). Sociological theory ( $7^{\text {th }}$ Ed.). New York: McGraw-Hill.

Sobormate, S. (2014). Environmental justice in Nigeria: Reflections on the Shell - Ogoni uprising, twenty years afterwards.

United Nations Environment Programme (2011). Environmental assessment of Ogoniland. Kenya: The United Nations environment Programme.

Uwaegbulam, C. (2020, September 14). National Assembly frown at the delay in the remediation on the polluted areas in Ogoniland, many years after UNEP submitted its report. The Guardian. Retrieved from httpsL//m.guardian.ng.

Yakubu, O. H. (2017). Addressing environmental health problem in Ogoniland through implementation of United Nations Environmental Programme recommendations: Environmental managemental strategies. Environments 4(28), doi:10.3390/ environments4020028. 